\title{
Autoantigen-specific T Cell Proliferation Induced by the Ribosomal P2 Protein in Patients with Systemic Lupus Erythematosus
}

\author{
Mary K. Crow, Gina DelGiudice-Asch, Julie B. Zehetbauer, John L. Lawson, Nathan Brot, * Herbert Weissbach, * \\ and Keith B. Elkon \\ Department of Medicine and The Specialized Center of Research on Systemic Lupus Erythematosus, The Hospital for Special Surgery \\ and Cornell University Medical College, New York 10021; and *The Roche Institute of Molecular Biology, Nutley, New Jersey 07110
}

\begin{abstract}
A role for helper $T$ cells in the induction of pathogenic lupus autoantibodies is increasingly supported by data from studies of murine lupus and patients with systemic lupus erythematosus (SLE). However, the poor in vitro function of SLE $T$ cells has hampered the identification and characterization of autoantigen-specific $T$ cells. We used recombinant fusion proteins to study the $T$ cell proliferative response of 31 lupus patients and 27 healthy subjects to a well-characterized SLE autoantigen, the ribosomal P2 protein. Although PBMC from SLE patients showed marked impairment in the proliferative response to the common recall antigen tetanus toxoid when compared with normal subjects, a significantly greater proportion of SLE patients $(32 \%)$ than normal individuals $(0 \%)$ showed a $T$ cell response to a recombinant $P 2$ fusion protein. When the SLE patients were subgrouped according to the presence of serum anti-P autoantibody, 7 of 10 anti-P antibody-positive patients, but 0 of 20 anti-P antibody-negative SLE patients, demonstrated $>2,000 \mathrm{cpm}\left[{ }^{3} \mathrm{H}\right]$ thymidine incorporation and a P2 stimulation index $>5$. The specificity of the $T$ cell proliferative response for the $P 2$ protein was confirmed by studies using a second recombinant human $P 2$ fusion protein and by the specific activation of $P 2$-primed $T$ cells by recombinant $P 2$ in secondary cultures. Moreover, the $T$ cell proliferative response to the $P 2$ autoantigen was mediated by CD4-positive $T$ cells and was inhibited by anti-MHC class II antibodies. These data demonstrate the presence of autoantigen-specific $T$ helper cells in patients with SLE and suggest that these $T$ cells drive the production of autoantibodies by B lymphocytes. (J. Clin. Invest. 1994. 94:345-352.) Key words: lupus erythematosus, systemic • T lymphocytes • autoantigens $\cdot$ ribosomal proteins $•$ autoimmunity
\end{abstract}

\section{Introduction}

Systemic lupus erythematosus (SLE), the prototypic systemic autoimmune disease, is characterized by B cell activation, hypergammaglobulinemia, and the presence of serum autoantibodies. Although the hypergammaglobulinemia of SLE is poly-

Address correspondence to Mary K. Crow, M.D., The Hospital for Special Surgery, 535 East 70th Street, New York, NY 10021.

Received for publication 18 January 1994 and in revised form 7 March 1994.

J. Clin. Invest.

(c) The American Society for Clinical Investigation, Inc. 0021-9738/94/07/0345/08 \$2.00

Volume 94, July 1994, 345-352 clonal, certain autoantibodies are present at strikingly high titers and bind to a limited number of self proteins (1). Particularly frequent are antibodies specific for proteins contained within complex intracellular particles, such as nucleosomes, small nuclear ribonucleoproteins (snRNPs), ${ }^{1}$ and ribosomes. Autoantibodies are thought to be responsible for many of the clinical manifestations of SLE, including glomerulonephritis, arthritis, and serositis.

The mechanisms that drive autoantibody production in SLE remain uncertain. However, accumulating evidence suggests that this process is both autoantigen driven and $\mathrm{T}$ cell dependent. Supporting an essential role for autoantigens in stimulating autoantibody production by B cells are the observations that SLE antisera react with several proteins located within the same particle and with multiple epitopes on the same antigen, and that autoantibodies to different epitopes on the same antigen fluctuate in parallel (for review see reference 2). Evidence supporting an essential role for T cells in SLE has predominantly been obtained from murine lupus (for review see reference 3 ) and includes the observations that neonatal thymectomy prevents or markedly ameliorates the SLE-like syndrome in both MRL and NZB/W F1 mice; treatment of NZB/W F1 and MRL/lpr mice with the anti-L3T4 monoclonal antibody reactive with the helper $T$ cell $\left(T_{h}\right)$ subset abrogates their systemic autoimmune disease; and the transfer of parental $\mathrm{T}$ cells into $\mathrm{F} 1$ recipient animals can result in a lupus-like syndrome (4). In human SLE, the evidence implicating T cells is indirect. The pathogenic antibodies are of the IgG isotype and are encoded by immunoglobulin genes that have undergone somatic mutation (5).

Although efforts to characterize autoantigen-specific $T$ cells in organ-specific autoimmune diseases such as multiple sclerosis, myasthenia gravis, and Graves' disease have met some success, it has been difficult to demonstrate that the proteins recognized as antigens by lupus autoantibodies can activate SLE $T$ cells. These difficulties are due in part to numerous in vitro SLE T cell functional deficits and to difficulties in purifying large amounts of native antigens by biochemical methods. The recent cloning and production in large quantities of several SLE autoantigens provide the opportunity to study the $\mathrm{T}$ cell response to these autoantigens. One well-characterized SLE antigen is the ribosomal $P 2$ phosphoprotein (for review see reference 6). Approximately $15 \%$ of all SLE patients, and the majority of patients with lupus psychosis (7), have anti-P antibodies that bind to a shared epitope on the carboxyl-terminal portion of $\mathrm{P} 0, \mathrm{P} 1$, and $\mathrm{P} 2$. We report our analysis of the $\mathrm{T}$ cell proliferative

1. Abbreviations used in this paper: $\mathrm{P} 2-\beta$-gal, $\mathrm{P} 2-\beta$-galactosidase fusion protein; rHuP2, recombinant human P2 fusion protein; SI, stimulation index; snRNP, small nuclear ribonucleoprotein; TCR, T cell receptor; $T_{h}, T$ helper cell; TT, tetanus toxoid. 
response to the recombinant P2 fusion protein in SLE patients and healthy individuals.

\section{Methods}

Study subjects. Patients with SLE ( $n=29)$, meeting at least four of the American Rheumatism Association revised criteria for the diagnosis of SLE (8), and patients with LE with discoid features $(n=2)$ were followed at The Hospital for Special Surgery Rheumatic Disease Clinic. Peripheral blood samples were obtained with permission of the patients. Apart from the specific attempt to recruit all lupus patients positive for anti-P antibodies, no other selection criteria were used for the inclusion of SLE patients in this study. Normal controls included 27 healthy approximately age-matched volunteers.

Expression of P2- $\beta$-galactosidase (P2- $\beta$-gal) and P2-TrpE fusion proteins ( $r H u P 2$ ). The lysogenic Escherichia coli strain Y 1089 was infected with a recombinant lambda phage containing the cDNA encoding the full-length human $\mathrm{P} 2$ protein (9). Protein expression was induced by a temperature shift to $45^{\circ} \mathrm{C}$ and by $10 \mathrm{mM}$ isopropyl/thiogalactosidase. Full-length human $\mathrm{P} 2$ fused to the TrpE protein and the control TrpE protein were created in the pATH series of plasmids (10). Proteins were expressed in E. coli strain HB101 after induction with 50 $\mu \mathrm{M}$ indoleacylic acid as described previously (11). To isolate overexpressed proteins, bacteria were harvested by centrifugation, and the insoluble proteins were recovered by the method of Adam et al. (12). As reported previously, the recombinant proteins were $90-95 \%$ pure as determined by densitometric scanning of Coomassie blue-stained polyacrylamide gels $(9,11)$. Total protein was measured by the method of Bradford (13). rHuP2 and control proteins were used at a final concentration $20 \mu \mathrm{g} / \mathrm{ml}$ in culture medium.

Additional antigens. Tetanus toxoid (TT; State Laboratory Institute, Jamaica Plain, MA) was used at a final concentration of $10 \mu \mathrm{g}$ protein/ $\mathrm{ml}$. Intact human ribosomes were isolated from HeLa cytoplasmic extracts by discontinuous sucrose density ultracentrifugation as described (14) and used at a final concentration of $25-50 \mu \mathrm{g} / \mathrm{ml}$. The $P 2$ protein comprises $\sim 2 \%$ of the ribosomal protein preparation.

Anti-P ELISA. The ELISA was performed as described (9). Briefly, microtiter wells were coated with $200 \mathrm{ng}$ of rHuP2 at $4^{\circ} \mathrm{C}$ overnight. The plates were washed with PBS $(0.15 \mathrm{M} \mathrm{NaCl}$ buffered with $10 \mathrm{mM}$ phosphate, $\mathrm{pH} 7.4$ ) and then blocked with $1 \%$ BSA for $1 \mathrm{~h}$ at room temperature. Serum samples (diluted 1:500 in PBS containing 0.05\% Tween-20 and $10 \%$ normal goat serum) were added to the wells. The plates were incubated at $37^{\circ} \mathrm{C}$ for $3 \mathrm{~h}$. Alkaline phosphatase-conjugated goat anti-human IgG, diluted 1:1,000 in PBS containing 10\% normal goat serum, was then added to the plates and incubation was performed for an additional hour at $37^{\circ} \mathrm{C}$. The reaction was developed with $p$ nitrophenylphosphate and the OD read at $405 \mathrm{~nm}$ with a Dynatech Multiscanner (Flow Laboratories, Inc., McLean, VA). Values $>3$ SD above the mean of 20 normal controls were considered positive.

Cell preparations. PBMC were isolated on Ficoll-Hypaque and incubated at $37^{\circ} \mathrm{C}, 5 \% \mathrm{CO}_{2}$ for $16-40 \mathrm{~h}$ at $2 \times 10^{6} / \mathrm{ml}$ in RPMI 1640 (Gibco Laboratories, Grand Island, NY) containing $10 \%$ fetal calf serum (Whittaker Bioproducts, Inc., Walkersville, MD), $2 \mathrm{mM}$ glutamine, and $50 \mathrm{U} / \mathrm{ml}$ penicillin and streptomycin (Gibco Laboratories). In some experiments, $T$ and non- $T$ cells were isolated after rosetting of $T$ cells with neuraminidase-treated sheep red blood cells, followed by fractionation of rosetted and unrosetted cells on Ficoll-Hypaque. CD8-depleted and CD4-depleted $\mathrm{T}$ cell populations were prepared by incubating PBMC with CD8 or CD4 mAb-coupled magnetic beads (Dynal, Oslo, Norway) at $4^{\circ} \mathrm{C}$ for $1 \mathrm{~h}$ followed by depletion of bead-bound cells with a magnet.

Antigen-specific $T$ cell proliferation assay. $1 \times 10^{5}$ PBMC were cultured in $200 \mu \mathrm{l}$ RPMI 1640 supplemented with $10 \%$ heat-inactivated normal human $\mathrm{AB}$ serum, $2 \mathrm{mM}$ glutamine, and $50 \mathrm{U} / \mathrm{ml}$ penicillin and streptomycin. Cells were cultured for $\mathbf{6 d}$ with medium alone, or with TT, rHuP2, control proteins ( $\beta$-gal or TrpE), or purified human ribosomes. All cultures were performed in triplicate. $2 \mu \mathrm{Ci}$ of $\left[{ }^{3} \mathrm{H}\right]$ thymidine
(New England Nuclear, Billerica, MA) were added to each microculture during the final $16 \mathrm{~h}$ of incubation and cultures were then harvested and counted in a liquid scintillation counter.

Secondary cultures were established after antigen stimulation of PBMC for 7-10 d. Blast cells were isolated from the $20 \% / 50 \%$ interface of a discontinuous Percoll (Pharmacia Fine Chemicals, Piscataway, NJ) gradient after centrifugation at $400 \mathrm{~g}$ for $12 \mathrm{~min}$. The cells $\left(1 \times 10^{4}\right)$ were then cultured for $3 \mathrm{~d}$ in the presence of $1 \%$ purified IL-2 (Schiapparelli Biosystems, Columbia, MD) in medium alone or with rHuP2, control proteins, or HeLa ribosomes. Autologous EBV-transformed B cell line cells $\left(5 \times 10^{3}\right)$ were used as antigen presenting cells. Incorporation of $\left[{ }^{3} \mathrm{H}\right]$ thymidine during the last $16 \mathrm{~h}$ of culture was determined as described above.

$m A b$. mAb used included OKT3 (anti-CD3, pan-T); OKT4 (antiCD4, helper/inducer subset); and OKT8 (anti-CD8, suppressor/cytotoxic subset) (American Type Culture Collection, Rockville, MD). $\mathrm{mAb}$ anti-Tac, reactive with the p55 chain of the IL-2 receptor, was obtained from Dr. Thomas Waldmann (National Institutes of Health). Anti-MHC class II mAb included mAb CR10-343, reactive with monomorphic DR determinants, and $\mathrm{mAb} 33.1$, reactive with a DQ1 determinant (obtained from Dr. Carlo Russo, Cornell University Medical College). Anti-T cell receptor (TCR) $\mathrm{V} \beta \mathrm{mAb}$ included $\mathrm{mAb} C 37$, reactive with $\mathrm{V} \beta$ 5.2,5.3; $\mathrm{mAb}$ OT145, reactive with $\mathrm{V} \beta$ 6.7a; and $\mathrm{mAb}$ S511, reactive with $\mathrm{V} \beta 12$ (obtained from Dr. David Posnett, Cornell University Medical College); and mAb C1, reactive with V $\beta 17$ TCR (15).

Flow cytometry analysis. $2 \times 10^{5} \mathrm{PBMC}$ were incubated with buffer alone or a saturating concentration of $\mathrm{mAb}$ at $4^{\circ} \mathrm{C}$ for $30 \mathrm{~min}$. Cells were then washed three times and incubated with a saturating concentration of fluorescein-labeled $\mathrm{F}\left(\mathrm{ab}^{\prime}\right)_{2}$ fragments of goat anti-mouse IgG (Tago, Inc., Burlingame, $\mathrm{CA}$ ) at $4^{\circ} \mathrm{C}$ for $30 \mathrm{~min}$. After three washes in buffer, cell fluorescence was analyzed on an Ortho IIs cytofluorograph, gating on the lymphocyte population.

Statistical analysis. The mean $\pm \mathrm{SD}$ of $\left[{ }^{3} \mathrm{H}\right]$ thymidine incorporation was determined for each subject group. Patient and control populations were compared and analyzed for statistically significant differences using Student's $t$ test, with $t$ determined for populations with unequal variance.

\section{Results}

Autoantibodies reactive with ribosomal $\mathrm{P}$ proteins are detectable in approximately $15 \%$ of randomly selected patients with SLE (6). Sera from 28 of the 29 SLE patients and from 2 patients with discoid LE were tested for anti-P reactivity by ELISA. The serum from one patient was not available for analysis. Because patients previously known to have anti-P antibodies were specifically recruited for this study, 9 of 28 (33\%) SLE patients and 1 of 2 discoid LE patients had elevated serum anti$\mathrm{P}$ antibodies. None of the normal controls were anti-P positive.

Stimulation of $T$ cell proliferation by $r H u P 2$. T cell proliferation in medium alone and in response to either a common recall antigen, TT, or to the autoantigen P2 were evaluated in short-term cultures established from 31 SLE patients (including 2 with discoid LE) and from 27 healthy control subjects. Baseline thymidine incorporation in these cultures was low in all of the study groups (Fig. 1 and Table I). When the proliferative responses to TT were compared, SLE patients showed a marked reduction compared with normal subjects $(P<0.001)$, but no significant differences were observed in SLE patients with $(+)$ or without (-) anti-P antibodies (Fig. 1, Table I). A poor response of SLE T cells to recall antigens, including TT, has been documented previously by others (16) and may be attributable to defects in IL-2 production (17) or IL-2 receptor expression (18), impaired accessory cell function (19), production of inhibitory cytokines (20), or other as yet uncharacterized 


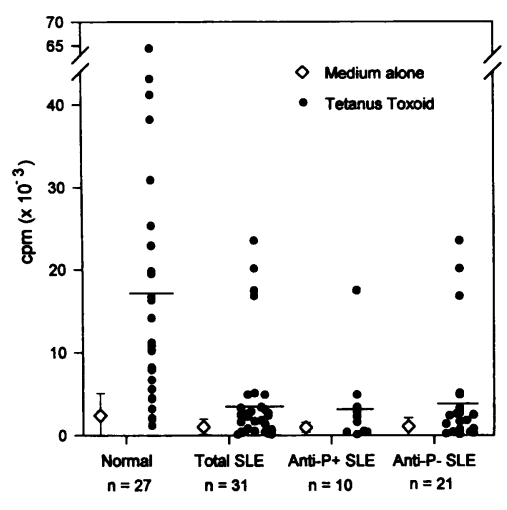

$\mu \mathrm{g} / \mathrm{ml}$ as described in

Methods. Results are expressed as cpm $\left[{ }^{3} \mathrm{H}\right]$ thymidine incorporated [ the mean \pm SD for medium alone and individual data points and the mean (short horizontal line) for tetanus toxoid].

mechanisms. Most SLE patients also showed poor proliferative responses to both rHuP2 and to the control fusion protein (Table I). However, when the proliferative responses to $\mathrm{rHuP2}$ and the control protein were compared in the same individuals, the total SLE and anti-P+, but not the anti-P-, SLE patients demonstrated significantly higher responses to the autoantigen $(P$ $<0.02$ ).

To address whether SLE anti-P+ patients had a relatively greater response to $\mathrm{rP} 2$ than the control study groups, the results were expressed as a Stimulation Index (SI) (calculated from $\mathrm{rHuP2} \mathrm{cpm} /$ control fusion protein $\mathrm{cpm}$ ). The SI was used to reduce the influence of the slightly higher background proliferation (with medium and the control protein) observed in normal controls and the reduced capacity of SLE T cells to respond to a recall antigen as described above (Table I). To avoid spurious results arising from very low counts per minute in "nonresponders," only those individuals with a T cell response $>2,000$ cpm were included in this analysis. When the P2 SI was compared between total SLE patients and normal controls, somewhat higher values were obtained in the SLE group $(P<0.05$; Fig. 2, Table I). Nine of $22(41 \%)$ SLE responders had a P2 SI $>3$, and $7(32 \%)$ of these SLE patients, including one with discoid LE, showed a P2 SI > 5. In contrast, of the 21 normal

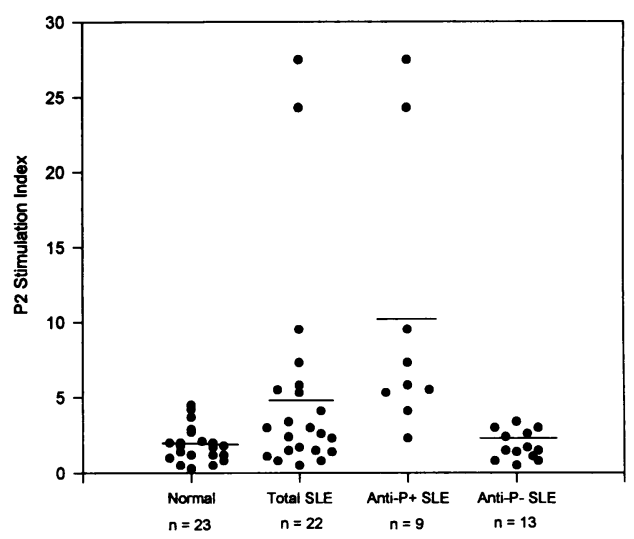

Figure 2. Stimulation of T cell proliferation by rHuP2. PBMC from normal individuals, patients with SLE (Total SLE), SLE patients with anti-P antibodies (anti-P+SLE), and SLE patients without anti-P antibodies (anti-P-SLE) were cultured for $6 \mathrm{~d}$ with rHuP2 (P2- $\beta$-gal) or with $\mathrm{r}$ control protein ( $\beta$-gal) at a final concentration of $20 \mu \mathrm{g} / \mathrm{ml}$ as described in Methods. Results are expressed as an SI, determined by $\mathrm{cpm}$ of cultures stimulated with $\mathrm{rHuP} 2 / \mathrm{cpm}$ of cultures stimulated with $r$ control protein. Statistical comparisons between the study groups are presented in Table I. Only individuals showing proliferative responses $>2,000 \mathrm{cpm}$ were included in this analysis.

subjects whose PBMC incorporated $>2,000 \mathrm{cpm}$, only 3 ( $14 \%$ ) had a P2 SI $>3$ and none had a SI $>5$. Thus, in spite of their marked impairment in antigen-specific $\mathrm{T}$ cell proliferation, as documented by the poor response to TT, more than one third of the SLE patients tested showed an augmented T cell response to $\mathrm{rHuP} 2$ when compared with the response to control protein.

Of the nine anti-P+ SLE responders, seven had a P2 SI > 5 (Fig. 2). None of the 20 anti-P - patients had a P2 SI $>5$. When the SI was compared between anti-P+ (SI, 10.2 \pm 9.2 ) and anti-P-SLE patients (SI, $1.8 \pm 1.0$ ), a striking difference was observed $(P<0.005)$. These results demonstrate an association between the presence of serum autoantibody specific for the $\mathbf{P}$ protein and the capacity of an individual's $\mathrm{T}$ cells to respond in vitro to the $\mathrm{P} 2$ fusion protein.

To further investigate the proliferative response to the $P$ autoantigen in the anti-P antibody-positive SLE patients, a

Table I. Mean T Cell Proliferative Responses of SLE Patients and Control Subjects

\begin{tabular}{|c|c|c|c|c|c|}
\hline \multirow[b]{2}{*}{ Subject group } & \multicolumn{4}{|c|}{$\left[{ }^{3} \mathrm{H}\right]$ Thymidine incorporated* } & \multirow[b]{2}{*}{$\mathrm{P} 2 \mathrm{SI}^{\ddagger}$} \\
\hline & Medium & TT & rHuP2 & Control protein & \\
\hline \multicolumn{6}{|c|}{$c p m \times 10^{-3}$} \\
\hline $\operatorname{SLE}(n=31)$ & $1.0 \pm 0.9$ & $4.2 \pm 6.1^{\S}$ & $5.2 \pm 6.0^{\|}$ & $2.2 \pm 2.4^{\|}$ & $5.2 \pm 7.1^{f}$ \\
\hline Anti-P+ SLE $(n=10)$ & $1.0 \pm 0.6$ & $3.4 \pm 5.2$ & $7.5 \pm 8.1 * *$ & $0.9 \pm 0.7 * *$ & $10.2 \pm 9.2^{\ddagger}$ \\
\hline Anti-P-SLE $(n=20)$ & $1.1 \pm 1.1$ & $4.5 \pm 6.8$ & $4.2 \pm 4.2$ & $2.8 \pm 2.7$ & $1.8 \pm 1.0^{\ddagger}$ \\
\hline Normal $(n=27)$ & $2.4 \pm 2.7$ & $16.5 \pm 15.4^{\S}$ & $7.4 \pm 6.7$ & $4.3 \pm 3.4$ & $2.1 \pm 1.2^{9}$ \\
\hline
\end{tabular}

* PBMC were cultured for $6 \mathrm{~d}$ with medium alone, TT, rHuP2 (either P2- $\beta$-gal fusion protein or P2-TrpE fusion protein), or control protein $\left(\beta\right.$-gal or TrpE) as described in Methods. Incorporation of $\left[{ }^{3} \mathrm{H}\right]$ thymidine during the last $16 \mathrm{~h}$ of culture was measured. Mean $\pm \mathrm{SD}$ cpm $\left[{ }^{3} \mathrm{H}\right]$ thymidine incorporated in each study group is shown. ${ }^{\ddagger}$ The mean ratio of $\mathrm{cpm}\left[{ }^{3} \mathrm{H}\right]$ thymidine incorporated in response to rHuP2 divided by that incorporated in response to control protein (termed P2 SI) is shown for each study group. Individuals whose PBMC incorporated $<2 \times 10^{-3} \mathrm{cpm}$ $\left[{ }^{3} \mathrm{H}\right]$ thymidine in response to $\mathrm{rHuP} 2$ were excluded from the P2 SI analysis. ${ }^{\S} P<0.001 . \quad$ " $P<0.02 . \quad{ }^{* *} P<0.05$. $\quad{ }^{\Uparrow} P<0.02$. 邦 $P<0.005$. 
dose-response study was performed (Fig. 3 ). T cells and non$\mathrm{T}$ cells from a high responder were cultured with TT, rHuP2, or the control fusion protein ( $\beta$-gal) at a range of concentrations from 1 to $20 \mu \mathrm{g} / \mathrm{ml}$. Although TT and $\beta$-gal stimulated $<1,000$ cpm $\left[{ }^{3} \mathrm{H}\right]$ thymidine incorporation at all doses studied, rHuP2 (P2- $\beta$-gal fusion protein) stimulated an incremental increase in proliferation with increased concentrations of the antigen, with $31,500 \mathrm{cpm}\left[{ }^{3} \mathrm{H}\right]$ thymidine incorporated by cells cultured with $\mathrm{rHuP2}$ at $20 \mu \mathrm{g} / \mathrm{ml}$ final concentration. Similar results were obtained in experiments using two other anti-P+ SLE patients.

Although the P2 SI was significantly higher in anti-P antibody-positive SLE patients than in anti-P antibody-negative patients or normal controls, the increased proliferation above background observed in normal PBMC cultured with either rHuP2 (P2- $\beta$-gal) or the control protein ( $\beta$-gal) raised the concern that contaminants in the antigen preparations could contribute to the proliferative responses observed. To provide additional support for the specificity of the P2 protein-stimulated response in the anti-P antibody-positive patients, a second recombinant $\mathrm{P} 2$ protein was used. A P2-TrpE fusion protein and appropriate control protein ( $\mathrm{TrpE}$ ) were prepared and their capacity to stimulate proliferation by PBMC compared with $\mathrm{P} 2-\beta$-gal and the control protein $\beta$-gal in two SLE patients and one normal subject (Table II). The two rHuP2 fusion proteins stimulated comparably high levels of $\left[{ }^{3} \mathrm{H}\right]$ thymidine incorporation by PBMC from one SLE patient, whereas neither rHuP2 protein stimulated PBMC proliferation in the normal subject. A second SLE patient showed greater $\left[{ }^{3} \mathrm{H}\right]$ thymidine incorporation in response to $\mathrm{P} 2-\mathrm{TrpE}$ than to $\mathrm{P} 2-\beta$-gal, but the background counts per minute of PBMC cultured in the absence of antigen were also higher in the P2-TrpE experiment. Only low level $\left[{ }^{3} \mathrm{H}\right]$ thymidine incorporation above background was observed with either control protein. Table II also illustrates that the proliferative response to $\mathrm{rHuP} 2$ was persistent over several months in a given patient.

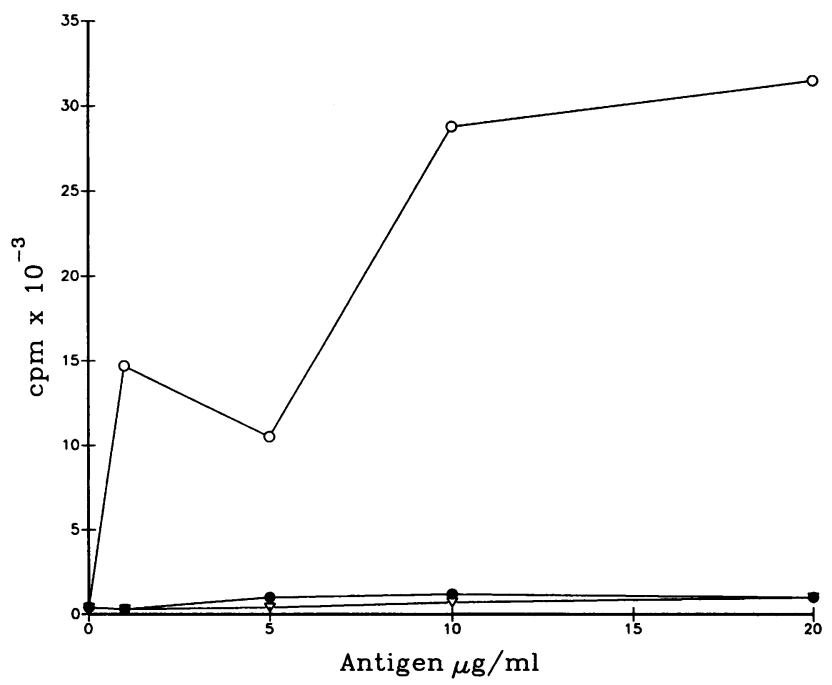

Figure 3. Dose response of SLE PBMC stimulated with rHuP2. $1 \times$ $10^{5}$ PBMC from an anti-P antibody-positive SLE patient were cultured for $6 \mathrm{~d}$ with TT (open triangles), $\mathrm{rHuP2}(\mathrm{P} 2-\beta$-gal) at a final concentration of 1-20 $\mu \mathrm{g} / \mathrm{ml}$ (open circles), or with $\mathrm{r}$ control protein at a final concentration of 1-20 $\mu \mathrm{g} / \mathrm{ml}$ (closed circles). Results are expressed as cpm $\left[{ }^{3} \mathrm{H}\right]$ thymidine incorporated.
The $\mathrm{P} 2$ phosphoprotein is one of $\sim 80$ proteins that, together with rRNA, make up the ribosomal ribonucleoprotein. To further demonstrate the capacity of PBMC from anti-P antibodypositive patients to proliferate in response to ribosomal autoantigens, biochemically purified human ribosomal proteins derived from HeLa cells were used as a source of antigen in proliferation assays. Although PBMC from four anti-P+ SLE patients who showed a P2 SI > 5 when stimulated with rHuP2 did not proliferate in response to the HeLa ribosome preparation (data not shown), three other SLE patients did demonstrate increased $\left[{ }^{3} \mathrm{H}\right]$ thymidine incorporation, $>2,000 \mathrm{cpm}$ and $\mathrm{SI}$ $>3$, when cultured with ribosome proteins (Table III). One of these patients was tested on two occasions and had a vigorous proliferative response to HeLa ribosome in both experiments. Proliferative responses were not observed when PBMC from three normal subjects were cultured with HeLa ribosome despite strong responses to TT. Thus, although less frequent than responses to $\mathrm{rHuP2}$, proliferative responses to purified ribosome preparations were observed in some anti-P+ SLE patients.

The proliferative response of SLE PBMC to $r H U P 2$ is a property of CD4-positive T cells and is inhibited by anti-MHC class II antibody. The $\mathrm{T}$ cell response to most soluble protein antigens is dependent on the presentation of antigenic peptides on MHC class II molecules expressed on antigen presenting cells and, at least in the initial phases of an immune response, is a property of the CD4-positive $T$ cell subset. To identify the $\mathrm{T}$ cell subset responsive to $\mathrm{rHuP2}$, proliferative responses to rP2 were compared between unfractionated PBMC and CD4- or CD8-enriched lymphocytes obtained from an anti-P antibodypositive SLE patient. As shown in Fig. 4, the proliferative response to rHuP2 was greater in the CD4-enriched cells whereas the CD8-enriched $\mathrm{T}$ cells showed much lower $\left[{ }^{3} \mathrm{H}\right]$ thymidine incorporation compared with the unfractionated cells. Flow cytometry analysis of another SLE patient's PBMC cultured with rHuP2 confirmed the selective expansion of CD4-positive $\mathrm{T}$ cells by the ribosomal autoantigen. The phenotype of the viable PBMC at day 7 of culture was $96 \%$ CD3 positive, 95\% CD4 positive, and $47 \%$ IL-2 receptor positive. A preliminary analysis of the TCR $\mathrm{V} \beta$ repertoire activated by $\mathrm{rHuP} 2$ did not reveal preferential expansion of $\mathrm{T}$ cells bearing $\mathrm{V} \beta$ 5.2, 5.3; 6.7a; 12 ; or 17 TCR (data not shown).

Fig. 5 illustrates the inhibition of antigen-induced $T$ cell proliferation by mouse anti-MHC class II mAbs. An anti-DR $\mathrm{mAb}, \mathrm{CR} 10-343$, used at $1 \mu \mathrm{g} / \mathrm{ml}$, inhibited TT-induced proliferation by normal $\mathrm{T}$ cells and $\mathrm{rHuP} 2$-induced proliferation by SLE $\mathrm{T}$ cells $>80 \%$. Of potential interest, an anti-DQ $\mathrm{mAb}$, 33.1, which did not inhibit TT-induced proliferation of normal $\mathrm{T}$ cells and which was modestly activating in control cultures, inhibited SLE $\mathrm{T}$ cell activation by $\mathrm{rHuP2}$ by $>50 \%$. Taken together, these data demonstrate that autoantigen-specific $\mathrm{T}$ cell proliferative responses in SLE, like soluble antigen-specific responses in normal subjects, are predominantly mediated by CD4-positive $\mathrm{T}$ cells and are dependent on MHC class II antigen interaction with $\mathrm{T}$ cells.

Specific induction of a secondary proliferative response by $r P 2$ autoantigen. Although the data thus far strongly support the presence of antigen-specific $T$ cells in SLE patients with anti-P antibodies, induction of a specific secondary response is required for a formal demonstration of antigen specificity. To address this issue, we used two experimental approaches. First, PBMC from an anti-P-positive patient with SLE were cultured with the $\mathrm{P} 2-\beta$-gal fusion protein for $7 \mathrm{~d}$. The viable cells were 


\begin{tabular}{|c|c|c|c|c|c|c|c|c|}
\hline \multirow[b]{3}{*}{ Stimulus } & \multicolumn{8}{|c|}{$\left[{ }^{3} \mathrm{H}\right]$ Thymidine incorporated ${ }^{*}$} \\
\hline & \multicolumn{2}{|c|}{ Normal subject } & \multicolumn{3}{|c|}{ SLE Anti-P+ } & \multicolumn{3}{|c|}{ SLE Anti-P+ } \\
\hline & $\mathrm{P} 2$ - $\beta$-gal & P2-TrpE & $\begin{array}{c}\mathrm{P} 2-\beta \text {-gal } \\
\text { experiment } 1\end{array}$ & $\begin{array}{c}\text { P2- } \beta \text {-gal } \\
\text { experiment } 2\end{array}$ & P2-TrpE & $\begin{array}{c}\mathrm{P} 2-\beta \text {-gal } \\
\text { experiment } 1\end{array}$ & $\begin{array}{c}\text { P2- } \beta \text {-gal } \\
\text { experiment } 2\end{array}$ & P2-TrpE \\
\hline & \multicolumn{8}{|c|}{$c p m \times 10^{-3}$} \\
\hline Medium & 0.8 & 0.9 & 6.0 & 0.4 & 1.5 & 1.3 & 0.1 & 7.1 \\
\hline TT & 25.3 & 38.6 & 2.3 & 0.5 & 0.4 & 1.1 & 0.1 & 4.6 \\
\hline rHuP2 & 1.7 & 2.0 & 55.5 & 30.2 & 37.0 & 2.9 & 7.3 & 18.8 \\
\hline Control protein & 2.9 & 3.1 & 5.3 & 1.1 & 3.7 & 0.3 & 0.3 & 3.7 \\
\hline
\end{tabular}

* PBMC from a normal subject and from two SLE patients with serum anti-P autoantibodies were cultured for $6 \mathrm{~d}$ with medium alone, rHuP2 (P2$\beta$-gal or $\mathrm{P} 2-\mathrm{TrpE})$, or a recombinant control protein ( $\beta$-gal or TrpE) as described in Methods, and $\left[^{3} \mathrm{H}\right]$ thymidine incorporation was measured during the last $16 \mathrm{~h}$ of culture. The data recorded for each individual are from from experiments performed on separate occasions.

then recultured with medium alone, the $\mathrm{P} 2-\mathrm{TrpE}$ fusion protein, the control TrpE protein, or with TT in the presence of autologous non-T cells (Fig. $6, A$ ). When $\left[{ }^{3} \mathrm{H}\right]$ thymidine incorporation was measured after $3 \mathrm{~d}$ of secondary culture, only rHuP2 induced proliferation of the primed $\mathrm{T}$ cells. This experiment provides strong support for the $\mathrm{P} 2$ specificity of the $\mathrm{T}$ cell response, as the priming and secondary stimulation were induced by $\mathrm{P} 2$ fusion proteins prepared with two different fusion partners (P2- $\beta$-gal and $\mathrm{P} 2-\mathrm{TrpE})$. As a second approach, PBMC from a different SLE patient were cultured for $10 \mathrm{~d}$ with rHuP2 and the low density (activated T cell-enriched) and high density (unactivated $\mathrm{T}$ cell-enriched) populations were isolated on a Percoll density gradient (Fig. 6, B). The low density, but not the high density, primed $\mathrm{T}$ cells were retriggered to proliferate when incubated for $3 \mathrm{~d}$ in secondary culture with rHuP2, irradiated autologous B cell line cells, and IL-2. These experiments clearly demonstrate that an antigen-specific secondary $\mathrm{T}$ cell response can be triggered in SLE T cells primed with the ribosomal P2 autoantigen.

\section{Discussion}

Increasing evidence supports the idea that autoantigen-specific $\mathrm{T}$ cells play an important role in human autoimmune diseases.

Table III. T Cell Proliferation Induced by Ribosomal Proteins

\begin{tabular}{|c|c|c|c|c|c|c|c|c|}
\hline \multirow[b]{3}{*}{ Stimulus } & \multicolumn{8}{|c|}{$\left[{ }^{3} \mathrm{H}\right]$ Thymidine incorporated $\left(\mathrm{cpm} \times 10^{-3}\right)^{*}$} \\
\hline & \multicolumn{4}{|c|}{ SLE Anti-P+ patients } & \multicolumn{4}{|c|}{ Normal subjects } \\
\hline & 1 & $2 \mathrm{a}^{\ddagger}$ & $2 b$ & 3 & 1 & $2 a^{\ddagger}$ & $2 b$ & 3 \\
\hline & \multicolumn{8}{|c|}{$\mathrm{cpm} \times 10^{-3}$} \\
\hline Medium & 0.2 & 3.2 & 4.3 & 2.2 & 0.2 & 1.0 & 2.0 & 1.0 \\
\hline TT & 5.7 & 3.7 & 3.2 & 1.5 & 41.2 & 16.3 & 22.7 & 16.3 \\
\hline HeLa ribosome & 3.5 & 11.3 & 35.4 & 6.8 & 0.1 & 1.5 & 1.0 & 2.0 \\
\hline
\end{tabular}

* PBMC from three anti-P+ SLE patients and three normal subjects were cultured for $6 \mathrm{~d}$ with medium alone, TT, or with isolated ribosomal proteins from HeLa cells, as described in Methods; $\left[{ }^{3} \mathrm{H}\right]$ thymidine incorporation was measured during the last $16 \mathrm{~h}$ of culture. ${ }^{\ddagger}$ SLE patient 2 and normal subject 2 were each assayed on two separate occasions ( $a$ and $b$ ).
MHC class II associations, antigen-specific T cell activation, and/or restricted $\mathrm{T}$ cell receptor $\mathrm{V} \beta$ gene utilization have been demonstrated in multiple sclerosis, myasthenia gravis, and Graves' disease (21-26). SLE patients have a significantly higher frequency of the HLA DR2 and DR3 haplotypes (for review see reference 27). Although these associations may in part be explained by independent associations with MHC class III products, class II polymorphisms are strongly associated with the presence of specific autoantibodies in SLE (27). Almost all patients with anti-Ro (SSA) antibodies had a glutamine at position 34 and/or a leucine at position 26 at the outermost domains of the HLA DQA1 and DQB1 chains, respectively (28). Because these residues map to the floor of the putative MHC class II antigen binding groove, this association is most readily explained by the preferential presentation of particular autoantigen-derived peptides by specific MHC class II products to $\mathrm{T}$ cells.

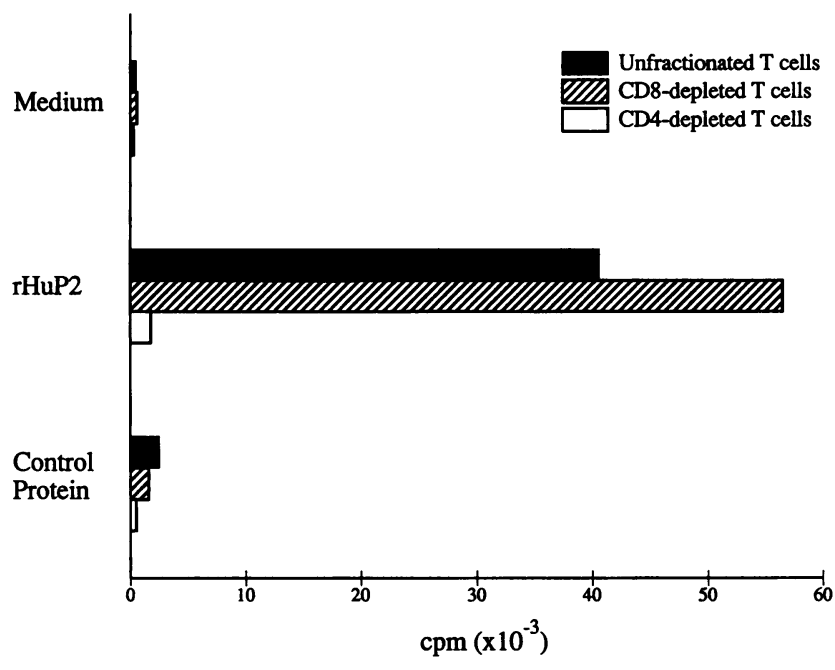

Figure 4. T cell proliferation stimulated by $\mathrm{rHuP} 2$ is primarily mediated by CD4-positive T cells. $1 \times 10^{5}$ PBMC (solid bar), CD8-depleted PBMC (hatched bar), or CD4-depleted PBMC (open bar) from an anti-P antibody-positive SLE patient were cultured for $6 \mathrm{~d}$ with culture medium alone, with $10 \mu \mathrm{g} / \mathrm{ml} \mathrm{rHuP2}$ (P2-TrpE), or with $10 \mu \mathrm{g} / \mathrm{ml} \mathrm{r}$ control protein (TrpE). Results are expressed as cpm $\left[{ }^{3} \mathrm{H}\right]$ thymidine incorporated. 


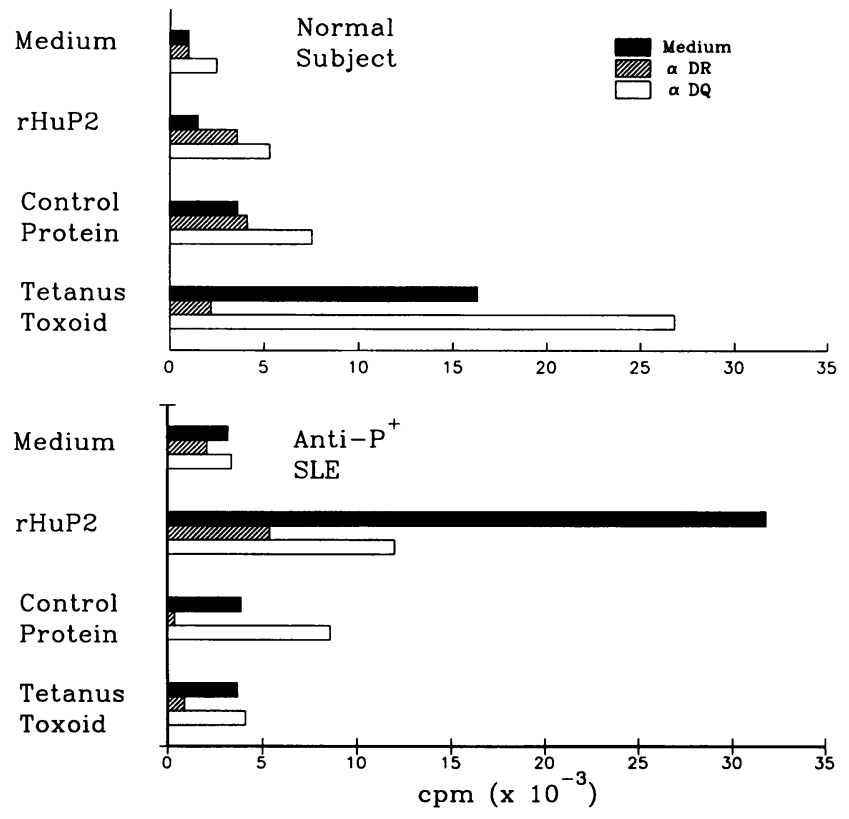

Figure 5. Inhibition of rHuP2-stimulated $\mathrm{T}$ cell proliferation by antiMHC class II mAb. PBMC from a normal subject (top) or an anti-P antibody-positive SLE patient (bottom) were incubated for $6 \mathrm{~d}$ in culture medium alone or with $\mathrm{rHuP2}$ ( $\mathrm{P} 2-\mathrm{TrpE}), \mathrm{r}$ control protein $(\mathrm{TrpE})$, or TT as described in Methods. Some cultures were supplemented with mAb specific for a framework determinant on DR (mAb CR10-343; hatched bars) or an $\mathrm{mAb}$ specific for a DQ1 determinant ( $\mathrm{mAb} 33.1$; open bars) used at a final concentration of $1 \mu \mathrm{g} / \mathrm{ml}$. Results are expressed as cpm $\left[{ }^{3} \mathrm{H}\right]$ thymidine incorporated.

Direct evidence for the involvement of $\mathrm{T}$ cells in autoantibody production in SLE and the closely related disease, mixed connective tissue disease, is, however, limited. CD4+, DRrestricted $\mathrm{T}$ cells from SLE patients have been propagated in vitro and found to provide help for the production of IgG antiDNA autoantibodies by autologous B cells (29). These $T_{h}$ cell lines proliferate in response to autologous antigen presenting cells, although their precise antigen specificity has not been defined. Recently, $T$ cell proliferative responses to ribonucleoprotein-derived protein antigens adsorbed to nitrocellulose membranes (30) and to either native (31) or recombinant (32, 33) U1-snRNP proteins in solution have been reported. Okubo et al. (32) demonstrated that $\mathrm{T}$ cell proliferation in response to a recombinant U1-snRNP A fusion protein occurred almost exclusively in patients with anti-snRNP antibodies. Furthermore, they demonstrated inhibition of U1-snRNP-stimulated T cell proliferation with anti-CD4 mAb reactive with the helper $\mathrm{T}$ cell subset and the presence of the responder $\mathrm{T}$ cells at relatively high frequency $(1: 4,000-1: 23,000)$.

The production of large quantities of the recombinant human ribosomal P2 autoantigen (9) has allowed us to study an autoantigen-specific $\mathrm{T}$ cell response in patients with SLE. Despite a marked deficiency in $T$ cell proliferation to the recall antigen tetanus toxoid, a significantly greater proportion of lupus patients had a $\mathrm{T}$ cell response to rHuP2 (arbitrarily defined as a greater than fivefold response compared with that obtained with the appropriate $r$ control protein ) compared with normal individuals. Most important, a significantly higher frequency of $\mathrm{T}$ cell proliferative responses to rHuP2 was observed in lupus patients

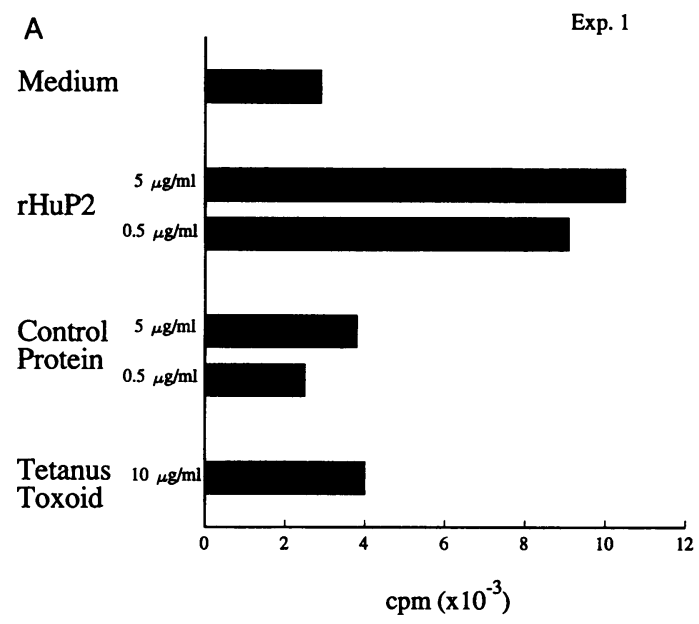

Exp. 2

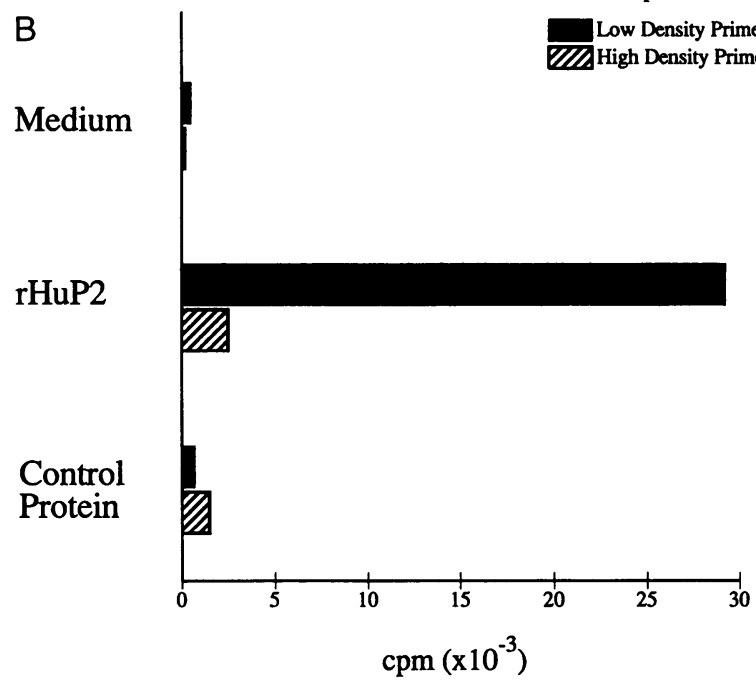

Figure 6. rHuP2-primed SLE T cells are specifically retriggered by rHuP2 in secondary cultures. In experiment 1 (top), PBMC from an anti-P antibody-positive SLE patient were stimulated in primary culture with $10 \mu \mathrm{g} / \mathrm{ml} \mathrm{P} 2-\beta$-gal. After $7 \mathrm{~d}$, viable cells were isolated by FicollHypaque centrifugation and $5 \times 10^{4} \mathrm{PBMC}$ incubated with $5 \times 10^{4}$ autologous non-T cells and culture medium alone, 5 or $0.5 \mu \mathrm{g} / \mathrm{ml} \mathrm{P2-}$ TrpE, 5 or $0.5 \mu \mathrm{g} / \mathrm{ml} \mathrm{r}$ control protein (TrpE), or $10 \mu \mathrm{g} / \mathrm{ml} \mathrm{TT}$. After $3 \mathrm{~d}$ of secondary culture, $\left[{ }^{3} \mathrm{H}\right]$ thymidine incorporation was determined. In experiment 2 (bottom), PBMC from a second anti-P antibody-positive patient were primed with $\mathrm{P} 2-\beta$-gal for $10 \mathrm{~d}$ as above. The cells were then fractionated on a discontinuous Percoll density gradient, the low density (activated cells) isolated from the $20 \% / 50 \%$ interface, and the high density (unactivated) cells isolated from the $50 \% / 100 \%$ interface. $1 \times 10^{4}$ low (solid bar) or high density (hatched bar) cells were cultured for $3 \mathrm{~d}$ with medium, P2- $\beta$-gal at $5 \mu \mathrm{g} / \mathrm{ml}$, or $\beta$-gal at $5 \mu \mathrm{g} /$ $\mathrm{ml}$ in the presence of $5 \times 10^{3}$ irradiated autologous EBV-transformed B cell line cells and $1 \%$ purified IL-2. Results are expressed as cpm $\left[{ }^{3} \mathrm{H}\right]$ thymidine incorporated.

with anti-P antibodies compared with lupus patients without anti-P, and both primary and secondary $\mathrm{T}$ cell responses were observed in individual patients with anti-P antibodies. These results cannot be explained by selection of an unusual subgroup of patients because SLE patients with anti-P are clinically and serologically similar to lupus patients in general (34) except for a higher incidence of anti-Sm antibodies (35) and lupus 
psychosis (7). Similarly, it is unlikely that drugs or disease activity influenced the results, because no significant differences in $\mathrm{T}$ cell proliferation to tetanus toxoid were observed in the anti-P antibody-positive and negative patient groups.

Because the purity of the $r$ proteins used in this study did not exceed $95 \%$, we cannot exclude the possibility that some of the $\mathrm{T}$ cell proliferative responses observed resulted from trace bacterial contaminants in the cultures. However, proliferative responses to bacterial contaminants cannot explain why $\mathrm{T}$ cell responses were preferentially observed with $\mathrm{P} 2$ fusion proteins rather than the control bacterial proteins and why responses were greater in SLE patients with anti-P antibodies compared with patients without a serologic response to P2. Furthermore, the similar proliferative responses observed in individual patients to recombinant $\mathrm{P} 2$ fusion proteins with different fusion partners and proliferation in response to biochemically purified ribosomes in some anti-P-positive patients indicate that the $\mathrm{T}$ cell proliferation described here was predominantly initiated by recognition of peptides derived from the human ribosomal P2 protein. The lack of complete concordance between the $T$ cell response to rHuP2 and the biochemically purified ribosomes may be due to differences in the quantity or form of the antigen or due to differences in the processing or presentation of the peptides by antigen presenting cells. In common with $T$ cell proliferative responses to soluble foreign protein antigens, the P2-reactive cells were predominantly CD4 positive and the proliferative response was inhibited by mAb to MHC class II antigens. Of potential interest is the observation that anti-DQ, as well as anti-DR, mAb inhibited the autoantigen-induced $\mathrm{T}$ cell response whereas the response to TT was only inhibited by anti-DR mAb. Studies are currently in progress to examine whether specific MHC class II alleles can be identified in SLE patients with $\mathrm{B}$ and $\mathrm{T}$ cell responses to $\mathrm{P} 2$.

Recent analyses of the trimolecular complex formed by the interaction of the TCR, antigenic peptide, and the MHC class II molecule show that the variable regions of the TCR bind to a linear peptide of between 16 and 25 residues located within the groove formed by the alpha helices of the MHC molecules (36). This being the case, it is difficult to explain how $\mathrm{T}$ cells are involved in the production of autoantibodies to nucleic acids in SLE. Possible mechanisms are suggested by murine studies showing "determinant spreading" in the course of a T cell immune response to autoantigen (37) and the recent demonstration that $\mathrm{T}$ cells activated by a foreign snRNP protein can drive the secretion of a linked set of autoantibodies reactive with other components of the murine snRNP particle (38). It has been suggested that, once $\mathrm{T}$ cell tolerance to one protein component of a complex protein-nucleic acid particle is broken, the subsequent immune response may readily extend to other components of the particle (38-41). This expanded repertoire of antibody specificities could then include reactivity to nucleic acids as well as proteins and could explain the presence of anti$28 \mathrm{~S}$ rRNA autoantibodies in $75 \%$ of SLE patients with anti-P $(42,43)$. These models do not rule out a potential concomitant role for antigen-nonspecific activation of $T_{h}$ cells, as may occur on exposure to microbial superantigens, in the differentiation of nucleic acid-specific B cells (44).

In conclusion, we have documented an autoantigen-specific $\mathrm{T}$ cell proliferative response in a high percentage of patients with serum autoantibodies directed against the ribosomal P2 protein. Characterization of the TCR genes and MHC restricting elements used by these cells, as well as investigation of their functional properties, should lead to considerable insight into the mechanisms of autoantibody production in systemic autoimmune disease.

\section{Acknowledgments}

The authors thank Dr. Steven M. Friedman for his helpful review of the manuscript and appreciate the assistance of Venus Te Eng Fo in the preparation of the manuscript.

This work was supported by the National Institutes of Health grants P50 AR42588 (SCOR, M. K. Crow, and K. B. Elkon), AI28367 (M. K. Crow), and AR38915 (K. B. Elkon), and by the Systemic Lupus Erythematosus Foundation (G. DelGiudice-Asch).

\section{References}

1. Gharavi, A. E., J. L. Chu, and K. B. Elkon. 1988. Autoantibodies in systemic lupus erythematosus are not due to random polyclonal B cell activation. Arthritis Rheum. 31:1337-1345.

2. Elkon, K. B. 1993. Autoantibodies in SLE. In Textbook of Rheumatology. P. Dieppe and J. Klippel, editors. Gower Medical Publishing, London. Section 6:4.1-4.10.

3. Theofilopolous, A. N., and F. J. Dixon. 1985. Murine models of systemic lupus erythematosus. Adv. Immunol. 37:269-290.

4. Gleichmann, E., E. H. van Elven, and J. P. van der Veen. 1982. A systemic lupus erythematosus (SLE)-like disease in mice induced by abnormal T-B cooperation: preferential formation of autoantibodies characteristic of SLE. Eur. J. Immunol. 12:152-159.

5. Davidson, A., A. Manheimer-Lory, C. Aranow, R. Peterson, N. Hannigan, and B. Diamond. 1990. Molecular characterization of a somatically mutated antiDNA antibody bearing two systemic lupus erythematosus-related idiotypes. $J$. Clin. Invest. 85:1401-1409.

6. Elkon, K. B., E. Bonfa, and N. Brot. 1992. Antiribosomal antibodies in SLE. Clin. Rheum. Dis. 18:377-390.

7. Bonfa, E., S. J. Golombek, L. D. Kaufman, S. Skelly, H. Weissbach, N. Brot, and K. B. Elkon. 1987. Association between lupus psychosis and antiribosomal P protein antibodies: measurement of antibody using a synthetic peptide antigen. N. Engl. J. Med. 317:265-271.

8. Tan, E. M., A. S. Cohen, J. P. Fries, A. T. Masi, D. J. McShane, N. F. Rothfield, J. G. Schaller, N. Talal, and R. J. Winchester. 1982. The 1982 revised criteria for the classification of systemic lupus erythematosus. Arthritis Rheum. 25:1271-1277.

9. Magsaam, J., A. E. Gharavi, A. P. Parnassa, H. Weissbach, N. Brot, and K. B. Elkon. 1989. Quantitation of lupus anti-ribosome $P$ antibodies using a recombinant P2 fusion protein and determination of the predicted amino acid sequence of the autoantigen in patients' mononuclear cells. Clin. Exp. Immunol. 76:165-171

10. Koerner, T. J., J. E. Hill, A. M. Myers, and A. Tzagoloff. 1991. High expression vectors with multiple cloning sites for construction of $\operatorname{trp} E$ fusion genes: pATH vectors. Methods Enzymol. 194:477-490.

11. Elkon, K. B., J. J. Hines, J. L. Chu, and A. P. Parnassa. 1990. Epitope mapping of recombinant $\mathrm{HeLa} \mathrm{SmB}$ and $\mathrm{B}^{\prime}$ peptides obtained by the polymerase chain reaction. J. Immunol. 145:636-643.

12. Adam, S. A., T. Nakagawa, M. S. Swanson, T. K. Woodruff, and G. Dreyfuss. 1986. mRNA polyadenylate-binding protein: gene isolation and sequencing and identification of a ribonucleoprotein consensus sequence. $\mathrm{Mol}$. Cell. Biol. 6:2932-2943.

13. Bradford, M. M. 1976. A rapid and sensitive method for the quantitation of microgram quantities of protein utilizing the principle of protein dye binding. Anal. Biochem. 72:248-254.

14. Elkon, K. B., A. P. Parnassa, and C. L. Foster. 1985. Lupus autoantibodies target the ribosomal P proteins. J. Exp. Med. 162:459-471.

15. Friedman, S. M., M. K. Crow, J. R. Tumang, M. Tumang, Y. Xu, A. S. Hodtsev, B. C. Cole, and D. N. Posnett. 1991. Characterization of human T cells reactive with the Mycoplasma arthritidis-derived superantigen (MAM). Generation of monoclonal antibody against $\mathrm{V} \beta 17$, the $\mathrm{T}$ cell receptor gene product expressed by a large fraction of MAM-reactive human T cells. J. Exp. Med. 174:891-900.

16. Gottlieb, A. B., R. G. Lahita, N. Chiorazzi, and H. G. Kunkel. 1979. Immune function in systemic lupus erythematosus. Impairment of in vitro T-cell proliferation and in vivo antibody response to exogenous antigen. J. Clin. Invest. 63:885-892.

17. Linker-Israeli, M., A. C. Bakke, R. C. Kitridou, S. Gendler, S. Gillis, and D. A. Horwitz. 1983. Defective production of interleukin 1 and interleukin 2 in patients with systemic lupus erythematosus (SLE). J. Immunol. 130:2651-2655.

18. Tanaka, T., O. Saiki, S. Negoro, T. Igarashi, T. Kuritani, H. Hara, M. 
Suemura, and S. Kishimoto. 1989. Decreased expression of interleukin-2 binding molecules (p70/75) in T cells from patients with systemic lupus erythematosus. Arthritis Rheum. 32:552-559.

19. Kuntz, M. M., J. B. Innes, and M. E. Weksler. 1979. The cellular basis of the impaired autologous mixed lymphocyte reaction in patients with systemic lupus erythematosus. J. Clin. Invest. 63:151-153.

20. DelGiudice G., K. Elkon, and M. Crow. 1993. TGF $\beta$ activity is increased in systemic lupus erythematosus (SLE) and progressive systemic sclerosis (PSS). Arthritis Rheum. 36:S196.

21. Sun J.-B., T. Olsson, W.-Z. Wang, B.-G. Xiao, V. Kostulas, S. Fredrikson, H.-P. Ekre, and H. Link. 1991. Autoreactive T and B cells responding to myelin proteolipid protein in multiple sclerosis and controls. Eur. J. Immunol. 21:14611468.

22. Link, H., O. Olsson, J.-B. Sun, W.-Z. Wang, G. Andersson, H.-P. Ekre, T. Brenner, O. Abramsky, and T. Olsson. 1991. Acetylcholine receptor-reactive $\mathrm{T}$ and $\mathrm{B}$ cells in myasthenia gravis and controls. J. Clin. Invest. 87:2191-2196.

23. Sun, J.-B., G. Harcourt, Z.-Y. Wang, S. Hawke, T. Olsson, S. Fredrikson, and H. Link. 1992. T cell responses to human recombinant acetylcholine receptor$\alpha$ subunit in myasthenia gravis and controls. Eur. J. Immunol. 22:1553-1559.

24. Liblau, R., E. Tournier-Lasserve, J. Maciazek, G. Dumas, O. Siffert, G. Hashim, and M.-A. Bach. 1991. T cell response to myelin basic protein epitopes in multiple sclerosis patients and healthy subjects. Eur. J. Immunol. 21:13911395.

25. Protti, M.-P., A. A. Manfredi, C. Straub, X. Wu, J. F. Howard, Jr., and B. M. Conti-Tronconi. 1990. Use of synthetic peptides to establish anti-human acetylcholine receptor $\mathrm{CD}^{+}$cell lines from myasthenia gravis patients. J. Immunol. 144:1711-1720.

26. Harrison, L. C., S. X. Chu, H. J. DeAizpurua, M. Graham, M. C. Honeyman, and P. G. Colman. 1992. Islet-reactive T cells are a marker of preclinical insulin-dependent diabetes. J. Clin. Invest. 89:1161-1165.

27. Arnett, F. C. 1992. Genetic aspects of human lupus. Clin. Immunol. Immunopathol. 63:4-6.

28. Reveille, J. D., M. J. Macleod, K. Whittington, and F. C. Arnett. Specific amino acid residues in the second hypervariable region of HLA-DQA1 and DQB1 chain genes promote the Ro (SS-A)/La (SS-B) autoantibody responses. 1991. J. Immunol. 146:3871-3876.

29. Rajagopalan, S., T. Zordan, G. C. Tsokos, and S. K. Datta. 1990. Pathogenic anti-DNA autoantibody-inducing $\mathrm{T}$ helper cell lines from patients with active lupus nephritis: isolation of CD4- CD8- $T$ helper cell lines that express the gamma-delta T-cell antigen receptor. Proc. Natl. Acad. Sci. USA. 87:70207024.

30. Pham, B. N., L. Prin, D. Gosset, P. Y. Hatron, B. Devulder, A. Capron, and J. P. Dessaint. 1989. T lymphocyte activation in systemic lupus erythematosus analyzed by proliferative response to nucleoplasmic proteins on nitrocellulose immunoblots. Clin. Exp. Immunol. 77:168-174.

31. Hoffman, R. W., T. Yoshihiko, G. C. Sharp, D. R. Lee, D. L. Hill, H. Kaneoka, and C. W. Caldwell. 1993. Human T cell clones reactive against $U$-small nuclear ribonucleoprotein autoantigens from connective tissue disease patients and healthy individuals. J. Immunol. 157:6460-6467.

32. Okubo, M., K. Yamamoto, T. Kato, N. Matsuura, T. Nishimaki, R. Kasukawa, K. Ito, Y. Mizushima, and K. Nishioka. 1993. Detection and epitope analysis of autoantigen-reactive $\mathrm{T}$ cells to the $\mathrm{U} 1$-small nuclear ribonucleoprotein $\mathrm{A}$ protein in autoimmune disease patients. J. Immunol. 151:1108-1115.

33. O'Brien, R. M., D. S. Cram, R. L. Coppel, and L. C. Harrison. 1990. Tcell epitopes on the 70-kDa protein of the (U1)RNP complex in autoimmune rheumatologic disorders. J. Autoimmun. 3:747-757.

34. Bonfa, E., and K. B. Elkon. 1986. Clinical and serological associations of the anti-ribosomal P protein antibody. Arthritis Rheum. 29:981-985.

35. Elkon, K. B., E. Bonfa, R. Llovet, and R. Eisenberg. 1989. Association between anti-Sm and anti-ribosomal P protein autoantibodies in human SLE and MRL/lpr mice. J. Immunol. 143:1549-1554.

36. Chicz, R. M., R. G. Urban, J. C. Gorga, D. A. A. Vignali, W. S. Lane, and J. L. Strominger. 1993. Specificity and promiscuity among naturally processed peptides bound to HLA-DR alleles. J. Exp. Med. 178:27-47.

37. Lehmann, P. V., T. Forsthuber, A. Miller, and E. E. Sercarz. 1992. Spreading of T-cell autoimmunity to cryptic determinants of an autoantigen. Nature (Lond.). 358:155-157.

38. Fatenejad, S., M. J. Mamula, and J. Craft. 1993. Role of intermolecular/ intrastructural B- and T-cell determinants in the diversification of autoantibodies to ribonucleoprotein particles. Proc. Natl. Acad. Sci. USA. 90:12010-12014.

39. Hardin, J. A. 1986. The lupus autoantigens and the pathogenesis of systemic lupus erythematosus. Arthritis Rheum. 29:457-460.

40. Carson, D. A. 1991. The specificity of anti-DNA antibodies in systemic lupus erythematosus. Arthritis Rheum. 146:1-2.

41. Mohan, C., S. Adams, V. Stanik, and S. K. Datta. 1993. Nucleosome. A major immunogen for pathogenic autoantibody-inducing T cells of lupus. $J$. Exp. Med. 177:1367-1381.

42. Uchiumi, T., R. R. Traut, K. B. Elkon, and R. Kominami. 1991. A human autoantibody specific for a unique conserved region of 28S ribosomal RNA inhibits the interaction of elongation factors 2 with ribosomes. J. Biol. Chem. 266:2054-2062.

43. Chu, J. L., N. Brot, H. Weissbach, and K. B. Elkon. 1991. Lupus antiribosomal P antisera contain antibodies to a small fragment of 28S rRNA located in the proposed ribosomal GTPase center. J. Exp. Med. 174:507-514.

44. Friedman, S. M., D. N. Posnett, J. R. Tumang, B. C. Cole, and M. K Crow. 1991. A potential role for microbial superantigens in the pathogenesis of systemic autoimmunity. Arthritis Rheum. 34:468-480. 